\title{
Cybertariat - prawo pracy a nowe formy zatrudnienia w ramach ekonomii wspótpracy
}

Cybertariat - labour law and the new forms of employment within gig-economy

\section{Wprowadzenie}

Prawna koncepcja stosunku pracy jest mocno zakorzeniona w epoce sprzed powstania Internetu. Tymczasem rozwój narzędzi cyfrowych w sposób fundamentalny i gwałtowny zmienia relacje świata pracy, powodując znaczną niepewność co do tego, jakie zasady obowiązują w cyberprzestrzeni tych, którzy dają pracę, i tych, którzy ją wykonują. Technologia sprawia, że tradycyjna i podstawowa cecha stosunku pracy, jaką była i jest podległość służbowa, ma coraz mniejsze znaczenie. Przedsiębiorstwa działające w ramach nowego modelu biznesowego (określanego terminami platform economy, gig economy, on-demand economy, sharing econom', peer-to-peer economy lub Uber economy) świadczą bowiem swoje usługi przy użyciu osób samozatrudnionych. Takie połączenie zmian organizacyjnych i technologicznych już na początku zeszłej dekady zostało określone jako „ucieczka od prawa pracy” (Baylos Brau, 2000, s. 35-36). Niektórzy autorzy twierdzą, że mamy już do czynienia ze zmierzchem podporządkowania pracownika $\mathrm{w}$ ramach stosunków zatrudnienia, a digitalizacja pracy stanowi "Zalążek nowego ładu społecznego" (Świątkowski, 2019, s. 15-16).

Najbardziej charakterystyczną formą wskazanego modelu biznesowego są tzw. platformy crowdworkingowe, na których zleceniodawcy składają oferty wykonania określonej usługi, a zleceniobiorcy mogą te oferty przyjąć (Howe, 2006). W teorii podmioty zarządzające daną platformą są wyłącznie pośrednikiem pomiędzy stroną podażową i popytową, prowadząc czy to stronę internetową, czy aplikację, gdzie klienci mogą znaleźć usługobiorcę, a ci ostatni określone zadanie 
do wykonania. Zarządzający platformami twierdzą, że prowadzą jedynie bazy danych ułatwiające zawieranie transakcji (de Stefano, 2016). Dlatego wszystkie osoby świadczące usługi w takim modelu są przez zarządców platform uznawane jako osoby samozatrudnione i niezależni przedsiębiorcy. W konsekwencji, wobec braku objęcia takich osób reżimem prawa pracy, usługi świadczone przez takie platformy są tańsze niż te świadczone w sposób tradycyjny.

Najpopularniejsze platformy obejmują usługi transportowe (Uber), pranie (FlyCleaners), sprzątanie (Helping), drobne naprawy (Myfixpert), edukację (Sharing Academy) czy mniejsze lub większe prace biurowo-komputerowe (Amazon Mechanical Turk). Większość platform wymaga pracy bezpośrednio z klientem albo w jego domu lub biurze, ale niektóre ograniczają się wyłącznie do pracy zdalnej. Istotne jest to, że klient platformy poszukuje określonej usługi świadczonej przez daną platformę. Zarządcy platform nie są więc zwykłym słupem ogłoszeniowym czy książką telefoniczną, gdzie można znaleźć każdy rodzaj usługi. Na danej platformie można wyszukać jedynie specyficzne, z góry określone usługi. (Odmienny charakter ma platforma Amazon Mechanical Turk, gdzie znaleźć można każdą usługę). Skutkuje to tym, że zarządcy platform zachowują wpływ na to, w jaki sposób usługa powinna być świadczona.

Dynamiczny i globalny rozwój platform stwarza także w Polsce istotne pytania dotyczące środowiska pracy. Dotyczą one tego, czy tradycyjne pojęcia „pracownik” i „pracodawca” mogą jeszcze odgrywać rolę w przypadku platform, oraz tego, czy stosunki zatrudnienia generowane i obsługiwane przez platformy nie powinny zostać objęte innym, nowym reżimem prawnym, który nie kładzie nacisku na element podporządkowania w procesie świadczenia pracy (Świątkowski, 2019). Tradycyjnie bowiem osoby samozatrudnione to takie, które oferują swoje usługi bezpośrednio więcej niż jednemu klientowi, nie stanowią elementu organizacyjnego żadnego przedsiębiorcy, same ustalają wynagrodzenie za swoje usługi, nie są związane instrukcjami co do sposobu świadczenia usług i mają swobodę w decydowaniu o przyjęciu zlecenia (Huws, 2003). Jak zostanie pokazane niżej, osoby świadczące pracę za pośrednictwem platform nie spełniają tych kryteriów, a ich przedsiębiorcza motywacja powinna być określona raczej jako przedsiębiorczość z konieczności (necessity entrepreneurship) niż przedsiębiorczość z możliwości (opportunity entrepreneurship) (Gaweł, 2019, s. 6). Okoliczność, że takie osoby wykonują usługi przy wykorzystaniu własnych narzędzi (komputer, smartfon, samochód), wydaje się nie mieć tu decydującego znaczenia, gdyż dziś są to podstawowe przedmioty codziennego użytku, wykorzystywane niezależnie do celów prywatnych i nie są one nabywane specjalnie na potrzeby świadczenia usług za pomocą platform. Celem artykułu jest analiza prawnego środowiska świadczenia 
pracy i usług za pośrednictwem platform oraz próba ujęcia zmodyfikowanych ram prawnych, którymi taka praca i takie usługi powinny być poddane. Autor przy pomocy metody formalno-dogmatycznej analizuje cechy pracy wykonywanej w ramach platform, a używając metod porównawczej i historycznej, sięga do dorobku zagranicznej jurysprudencji oraz tradycyjnych ram pracy nakładczej.

\section{Cechy uberyzacji}

W Polsce najsłynniejszą platformą specyficznych usług wykonywanych w trybie offline i organizowanych w systemie platform crowdworkingowych jest Uber. Aplikacja ta pozwala użytkownikowi zlokalizować w środowisku miejskim najbliższego kierowcę i zamówić podróż. Uber nie zatrudnia kierowców i nie jest właścicielem samochodów. Kandydaci na kierowców muszą zarejestrować się w systemie, przesłać dokumenty pojazdu i ubezpieczenia oraz prawo jazdy. W wybranych miastach Uber sprawdza znajomość topografii, a w niektórych wymagana jest także rozmowa kwalifikacyjna. Klient platformy płaci za usługę cenę ustaloną przez Uber - nie jest ona w żaden sposób negocjowalna, wpływu na nią nie ma również kierowca. Od wartości usługi Uber pobiera tytułem swojego wynagrodzenia od 10 do $20 \%$. Zakazane jest przyjmowanie napiwków. Ocena jakości usługi pozostawiona jest klientom-pasażerom - to oni wystawiają na platformie opinię kierowcy i jego kompetencjom po zrealizowaniu podróży. Jeśli taki „rating” kierowcy spadnie poniżej określonego progu, Uber może deaktywować konto kierowcy i tym samym jego dostęp do platformy (konto może zostać zablokowane także z innych powodów, np. krytykowania platformy w mediach społecznościowych - Huet, 2014). Uber oczekuje, że kierowca będzie akceptował wszystkie przychodzące do niego zlecenia; jeśli liczba odmów przyjęcia usługi spada, Uber wszczyna wewnętrzną procedurę weryfikacyjną. Platforma zachęca kierowców do noszenia profesjonalnego ubioru, sugeruje, by wyłączyć muzykę, otwierać pasażerom drzwi i wozić parasolkę. Kierowca ponosi wszystkie koszty związane z utrzymaniem pojazdu (paliwo, ubezpieczenie, eksploatacja), jak i godzi się na wyłączną odpowiedzialność za zdarzenia komunikacyjne. Cały kontakt między klientem platformy a kierowcą odbywa się poprzez platformę (klient i kierowca nie widzą nawet swoich numerów telefonicznych, kiedy ze sobą rozmawiają).

Powyższe pozwala wyodrębnić pewne cechy środowiska pracy świadczonej za pośrednictwem platform takich jak Uber (leksyka ma tu duże znaczenie oficjalnie kierowcy pracują „z Uberem”, a nie „dla Ubera”). 
Po pierwsze, zarządca platformy nie musi weryfikować jakości pracy świadczonej na jego rzecz, za którą pobiera wynagrodzenie od klientów platformy. Ocena pracy należy do klientów platformy. Na podstawie tej oceny konto danego usługodawcy może zostać zablokowane (wobec dalej poczynionych uwag nasuwa się tu wątpliwość, czy taka dezaktywacja konta może być potraktowana jako wypowiedzenie umowy o pracę). Platforma deleguje więc do klientów swoje uprawnienie do monitorowania pracy usługodawców. W konsekwencji nie musi ona udzielać usługodawcy konkretnych poleceń czy wskazówek dotyczących danego zlecenia - przekazuje tylko wspomniane sugestie co do ogólnego sposobu wykonywania usług. Jednak w praktyce te miękkie sugestie traktowane są jako twarde polecenia i ich zignorowanie może skutkować dezaktywacją konta (De Pillis, 2015; Manjoo, 2015). Co istotne - platforma, dzięki postępowi w zakresie tzw. big data i sztucznej inteligencji, ma możliwość ciągłego monitorowania usługi w sposób, jaki nigdy dotąd nie był możliwy (Sprague, 2015, s. 59-60). Nie jest tu więc w ogóle potrzebny tradycyjny i kosztowny poziom menadżerów średniego szczebla. W konsekwencji, wobec braku wskazówek co do sposobu wykonania usługi, usługodawca staje się odpowiedzialny za efekt, a nie za sposób świadczenia usługi (Cherry, 2016).

Po drugie, wobec tego, że oceny jakości pracy dokonuje klient platformy, ta ostatnia nie oferuje żadnych szkoleń czy treningów dla osób, które za jej pośrednictwem chcą świadczyć usługi. Innymi słowy: pulę osób świadczących usługi ma tu zweryfikować sam rynek, a nie platforma.

Po trzecie, platforma nie wydaje poleceń związanych z konkretną usługą, a jedynie ogólne instrukcje co do sposobu świadczenia usług jej klientom. Usługodawca zachowuje więc pewien margines swobody. Nie oznacza to jednak, że nie jest on uzależniony od platformy. Istotna różnica sprowadza się bowiem do rozróżnienia, jaką kontrolę platforma faktycznie sprawuje, a jaką może sprawować, gdy tylko zechce. Okoliczność, że usługodawcy mogą wybierać, kiedy i ile pracują, nie oznacza przecież, że są samozatrudnieni, bo w dzisiejszych czasach technologia pozwala na tak daleko idący monitoring, że określenie takich czynników, jak godzina rozpoczęcia pracy, nie jest konieczne. Co więcej, platforma w każdej chwili może jednostronnie zmienić wydane instrukcje. Jest to o tyle istotne w kontekście dalszego wywodu, że tradycyjnie polecenia przełożonego są na gruncie prawa pracy traktowane jako podstawowe narzędzia wpływu na personel (Jankowiak, 2001).

Po czwarte, celem platformy jest zakumulowanie jak największej liczby użytkowników i usługodawców. Dzięki temu tych drugich nie trzeba przeszkalać ani wydawać im konkretnych poleceń co do godzin pracy, gdyż pula usługodaw- 
ców jest tak duża, że klient zawsze znajdzie chętnego do wykonania zlecenia. Ta potrzeba osiągnięcia przez platformę określonej masy krytycznej może też prowadzić do sytuacji monopolistycznych lub oligopolistycznych. Wskazać także trzeba, że regulaminy platform zwykle pozwalają klientom w sposób zupełnie dowolny odmówić odbioru wykonanego dzieła bez obowiązku zapłaty.

Po piąte, replikowanie platformy można bez trudu przeprowadzać w kolejnych państwach. Ułatwia to osiągnięcie wspomnianej wyżej masy krytycznej usługodawców oraz klientów. Ma to także taki skutek, że pozycja negocjacyjna platformy wobec usługodawcy jest o wiele silniejsza (Hong, 2015). Powoduje to oczywistą nierówność, która każe, niejako bezrefleksyjnie i intuicyjnie, zastanowić się, czy taki usługodawca nie zasługuje na ochronę ze strony prawa pracy. Średnie wynagrodzenie za godzinę pracy na platformie Amazon Mechanical Turk to 2 dolary amerykańskie (Semuels, 2018). Trzeba tu także wskazać, że usługodawca nie może przenosić swojego konta z jednej platformy na inną, a tym samym nie ma możliwości tworzenia historii swojej pracy czy sieci rekomendacji.

Po szóste, nie jest przesądzone, czy platformy jedynie dostarczają dane stronom transakcji, czy też świadczą usługę w danej branży (transportowej, gastronomicznej bądź edukacyjnej). Ma to oczywiście kapitalne znaczenie. Jeśli platforma jest tylko bazą danych ułatwiającą kontakt między usługodawcą a usługobiorcą, to nie może ponosić odpowiedzialności za szkody powstałe w związku z tą usługą oraz nie musi wówczas podlegać regulacjom sektorowym. W interesującym judykacie Europejski Trybunał Sprawiedliwości (Wyrok TS z 20.12.2017 r., C-434/15, pkt 50) uznał, że Uber świadczy usługę transportową, gdyż poprzez instrukcje co do sposobu świadczenia usług, zachowuje wpływ na to, w jaki sposób te usługi są wykonywane. Warto tu zwrócić uwagę, że platformy nie pobierają od klientów wynagrodzenia za dostęp do swoich baz danych, ale za wykonanie konkretnej usług (Aloisi, 2016). Klienci nie korzystają przecież ze wskazanych platform dlatego, że mają tam bazę osób gotowych do przyjęcia zlecenia, ale dlatego, że chcą konkretnej usługi od konkretnej platformy. Także $\mathrm{z}$ tego powodu platformy zachowują wpływ na sposób świadczenia usług, bo od tego zależy ich reputacja i dlatego też mogą deaktywować konta usługodawców. Ponadto, jeśli platformy, jak same utrzymują, są tylko pośrednikami między klientem a usługodawcą, to być może pełnią one funkcję agencji pracy tymczasowej i powinny w konsekwencji być regulowane podobnie jak takie agencje lub jako instytucje pośrednictwa pracy (Gospodarek, 2019a, s. 12).

Po siódme, usługodawca jest częścią organizacji platformy. Klient, który z niej korzysta, widzi tylko cyfrową infrastrukturę platformy i traktuje usługodawcę jako przedstawiciela platformy. Nabiera to szczególnego charakteru przy pra- 
cach zdalnych, gdzie klient w ogóle nie ma realnego kontaktu z usługodawcą: obie strony kontaktują się za pomocą programów platformy. Fakt, że usługodawca jest właścicielem narzędzi do świadczenia usługi, nie powinien tu mieć znaczenia. Ochrona prawno-pracownicza powstała w czasach, gdy narzędzia i materiały znajdowały się głównie w fabrykach i właściwie nie mogły należeć do pracowników. Dziś narzędziem pracy może być samochód prywatny czy osobisty telefon, a więc przedmioty, które ma większość społeczeństwa. Tym samym fakt wykonywania pracy za pomocą własnych narzędzi nie powinien już mieć znaczenia dla kwalifikacji danej pracy jako wykonywanej w ramach stosunku pracowniczego. Innymi słowy - to, że się jest ich właścicielem, nie oznacza, że nie potrzebuje się ochrony (Rogers, 2016). Współcześnie głównym środkiem produkcji staje się technologia. W porównaniu z nakładami finansowymi na stworzenie platformy i powiązanych z nią aplikacji oraz programów koszt narzędzi usługodawcy jest śladowy.

Po ósme, usługodawcy nie wnoszą do platformy żadnej wartości dodanej poza swoją pracą. Tradycyjnie osoby samozatrudnione były i są angażowane dlatego, że mają określone doświadczenie, kompetencje i umiejętności, których nabywca nie ma. Tymczasem usługodawca nie oferuje platformie żadnej takiej wartości (platforma tego nie oczekuje). Know-how platformy jest przekazywany usługodawcom za pomocą instrukcji i rekomendacji; nie pochodzi on od usługodawców. Co więcej, osoba "tradycyjnie” samozatrudniona może samodzielnie pozyskiwać nowych klientów i rozwijać swoje przedsiębiorstwo; w przypadku platform takie możliwości są wykluczone (Marvit, 2014).

Z powyższego wynika, że osoby świadczące usługi równocześnie dla platformy i poprzez platformę nie spełniają warunków osoby samozatrudnionej. Niektórzy autorzy podnoszą, że jedynym powodem, dla którego takie zatrudnienie nie jest traktowane jak zatrudnienie pracownicze, jest nowatorski i cyfrowy charakter platform (Cherry, 2009; Cherry, 2016; Rogers, 2016). Niektóre orzeczenia sądów angielskich (Wyrok England and Wales Court of Appeal (Civil Division), 2018; Gospodarek, 2019b) i amerykańskich (Wyrok United States Court of Appeal for the Ninth District, 2015) ${ }^{1}$ uznały kierowców platform - odpowiednio Uber i Lyft - za pracowników. Wskazuje się także, że ochronnymi przepisami prawa pracy powinni być objęci wszyscy usługodawcy, których autonomia jest $w$ trakcie świadczenia usług ograniczona (Davidov, 2016, s. 29-32).

1 W uzasadnieniu tego orzeczenia przeczytać można, że „próbować określić, czy ktoś jest dziś pracownikiem, to jak dać komuś kwadratowy kołek i poprosić, by wybrał, w którą z okrągłych dziur go wpasować. Dwudziestowieczne narzędzia pomocne w klasyfikowaniu pracy i pracowników nie są już użyteczne w XXI wieku”. 
Wydaje się jednak, że takie podejście jest zbyt totalne. Oznaczałoby ono bowiem konieczność stosowania do usługodawców platform całego bagażu prawa pracy, a niektóre z regulacji prawno-pracowniczych po prostu nie pasują do nowego modelu biznesowego. Ponadto poziom ochrony, jaki był i jest pożądany $w$ tradycyjnych sektorach gospodarki, nie jest potrzebny w ramach tych platform. Usługodawcy platform pracują przede wszystkim, kiedy chcą, co kłóci się z regulacjami z zakresu czasu pracy czy urlopów. Podobnie stałe miesięczne wynagrodzenie i płaca minimalna nie wydają się optymalne w modelu, gdzie to świadczeniodawca decyduje, jak długo pracuje (Weber \& Turcios, 2015).

Wydaje się więc, że należy poszukać innych rozwiązań prawnych.

\section{Specustawa dla cybertariatu?}

Jednym z potencjalnych modeli uregulowania pracy świadczonej za pośrednictwem platform jest specustawa dedykowana takiej formie zatrudnienia, gdzie podmiot zarządzający platformą występowałby w roli pracodawcy osób świadczących pracę za pośrednictwem tejże platformy. Swoje odrębne regulacje pracownicze mają w Polsce różne zawody, jak: kierowcy (Ustawa z 16.04.2004 r. o czasie pracy kierowców), nauczyciele (Ustawa z 26.01.1982 - Karta Nauczyciela), diagności laboratoryjni (Ustawa z 27.07.2001 r. o diagnostyce laboratoryjnej) czy pielęgniarki (Ustawa z 15.07.2011 r. o zawodach pielęgniarki i położnej). Celem wszystkich takich specprzepisów jest adaptacja ogólnych reguł prawa pracy do specyficznych warunków danego zawodu. Wydaje się, że wykorzystanie tego rodzaju instrumentu w odniesieniu do osób świadczących usługi poprzez platformy spełniłoby takie adaptacyjne zadanie -chroniłoby słabszą stronę danego stosunku prawnego (usługodawcę), a zarazem pozwalałoby platformie na rozwój swojego modelu biznesowego w dotychczasowej postaci. Brak takiej regulacji oznaczać będzie pozostawienie usługodawców takich platform samym sobie i wykluczenie ich $\mathrm{z}$ ram prawa pracy - a tradycyjnym celem prawa pracy jest przecież ochrona słabszej strony stosunku zatrudnienia (Florek, 1990; Skąpski, 2006, s. 69-98; Pisarczyk, 2012, s. 3-79). Obecna inercja ustawodawcy skutkuje tym, że podmioty zarządzające platformami określają standardy panujące w ramach gig-economy i narzucają swoje warunki (Zatz, 2011). Tymczasem, jak pokazują wskazane wyżej faktyczne okoliczności wykonywania usług w ramach platform przez osoby samozatrudnione, przewagi konkurencyjne platform nad tradycyjnymi modelami biznesowymi nie wynikają z ich lepszej organizacji czy większej wydajności, lecz po prostu z obejścia przepisów prawa pracy. Tym 
samym ustawa dedykowana pracy osób świadczących usługi poprzez platformy stanowiłaby istotne narzędzie w zapobieganiu nieuczciwej konkurencji i socjalnemu dumpingowi.

Taka dedykowana regulacja powinna objąć zarówno osoby, które za pośrednictwem platform świadczą usługi zdalnie, jak i w trybie offline, oraz powinna chronić pozycję usługodawców na równi z ochroną przyznawaną pracownikom przepisami prawa pracy, z zastrzeżeniem zakreślonych niżej różnic. Specustawa obejmująca pracę „na platformach” powinna zatem w szczególności regulować poniższe kwestie.

Polecenia/instrukcje. Istnienie poleceń dotyczących pracy nie powinno być traktowane jako przesądzające o istnieniu stosunku pracy. Przeciwnie: rodzaj pracy za pośrednictwem platform pokazuje, że ochrona słabszej strony stosunku zatrudnienia potrzebna jest również tam, gdzie brak jest poleceń pracodawcy dotyczących pracy (Todoli-Signes, 2017). Specustawa dla cybertariatu powinna zatem uwzględniać, że pracownikiem może być także osoba, która w zakresie wykonywania swoich obowiązków zachowuje dużą swobodę i nie jest związana instrukcjami pracodawcy. Platforma mogłaby zatem jedynie wydawać ogólne i niezbędne instrukcje określające ramy świadczenia usług, a pracownicy byliby zobowiązani do poruszania się w tak zakreślonych ramach i mieliby swobodę tego, jak wykonać konkretną usługę.

Swoboda w zakresie czasu pracy. Dedykowana specustawa powinna uwzględniać swobodę pracowników w ustalaniu własnego czasu pracy. Wydaje się, że jest to najistotniejsza cecha modelu pracy cybertariatu. Pracodawcy mogliby zachowywać wpływ na ustalanie minimalnej liczby godzin, jakie pracownik powinien w tygodniu przepracować, decydując w ten sposób, czy dana osoba pracuje na pełen etat, czy w innym wymiarze. Nowa regulacja mogłaby także wskazywać maksymalną liczbę godzin pracy dla różnych platform w określonej jednostce czasu.

Swoboda $w$ pracy dla różnych platform. Specustawa powinna zezwalać na to, by pracownicy mogli świadczyć usługi za pośrednictwem różnych platform i by mogli przenosić swoje konta, historię zatrudnienia i reputację (wynikającą z ocen klientów) na inne platformy. Bez takiej regulacji obecnie działające platformy mogą łatwo zmonopolizować rynek i znacząco utrudnić wejście na niego nowym podmiotom. Obecna polityka dezaktywacji kont usługodawców powoduje także, że są oni pozbawieni możliwości zakwestionowania decyzji platformy o odsunięciu ich od świadczenia pracy, co znacząco osłabia ich pozycję negocjacyjną, gdy historia ich zatrudnienia znika wraz z podjęciem pracy na nowej platformie. Jak stwierdził Lukas Biewald, prezes platformy Crowdflower, 
„przed epoką Internetu trudno było znaleźć kogoś do pracy na 10 minut i po tych 10 minutach zwolnić. Dziś dzięki technologii jest to możliwe - znajdujesz taką osobę, płacisz jej drobne i zaraz potem się jej pozbywasz" (Mian, 2016).

Odpowiedzialność odszkodowawcza pracowników. Brak związania pracowników poleceniami pracodawcy powinien skutkować brakiem odpowiedzialności platformy za szkody wyrządzone przez pracowników w trakcie świadczenia usługi. Tradycyjnie pracownicy ponoszą taką odpowiedzialność, gdyż są traktowani jako przedstawiciele pracodawcy, wykonujący jego polecenia. Tymczasem większa wolność w sposobie wykonywania pracy powinna skutkować zwiększoną odpowiedzialnością wobec klientów platformy.

Płaca minimalna. W sytuacji, gdy pracownik może decydować, ile godzin pracuje, i robi to, kiedy chce, istnienie miesięcznego wynagrodzenia minimalnego jest nie do utrzymania. Do pomyślenia jest zatem przykładowo ustalenie minimalnej stawki godzinowej za czas poświęcony na wykonanie zlecenia oraz określona forma ryczałtu za pozostawanie w gotowości do przyjęcia zlecenia.

Zwrot kosztów. Specustawa może przewidywać uprawnienie platformy do ustalenia, jakie przedmioty pracownik powinien posiadać, by zacząć pracę (np. samochód, telefon czy komputer). Będą to zwykle powszechne już dziś dobra, które pracownik i tak wykorzystuje do celów prywatnych i które większość czasu na siebie nie zarabiają. Wydaje się, że koszty tych przedmiotów powinien pokrywać pracownik, a na pracodawcę powinny przypadać koszty bieżące (np. paliwo).

Pomocnicze stosowanie Kodeksu pracy. Nowa regulacja powinna przewidywać odpowiednie stosowanie Kodeksu pracy do spraw w niej nieuregulowanych.

\section{Pracodawca funkcjonalny?}

Innym rozwiązaniem sytuacji osób świadczących pracę za pośrednictwem platform crowdworkingowych jest zmiana dotychczasowego paradygmatu pojęcia "pracodawca”. Obowiązujący binarny podział zakłada, że po stronie pracodawcy mamy do czynienia z jednym podmiotem. Tymczasem okoliczności świadczenia pracy w ramach platform pokazują, że często mamy do czynienia ze stosunkami multilateralnymi pomiędzy klientem platformy, samą platformą a usługodawcą (Felstiner, 2011). Relacja, która tu powstaje, zachodzi między klientem a platformą, między platformą a usługodawcą, a wreszcie między usługodawcą a klientem (Weil, 2014).

Tradycyjna analiza stosunków zatrudnienia sugerowałaby podział wskazanych relacji na trzy różne płaszczyzny, a następnie opis każdej z nich. Wydaje się 
jednak, że suma tych relacji umownych nie odzwierciedla rzeczywistego położenia ekonomicznego pracownika/usługodawcy. Konieczne jest zatem odejście od optyki indywidualnych stosunków umownych w ramach platformy na rzecz analizy multi-kryterialnej i funkcjonalnej, która pozwoli zaradzić trudnościom stawianym prawu pracy przez takie - trójstronne czy nawet wielostronne - relacje zatrudnienia.

Jak podnoszą Paul Davies i Mark Freedland, charakter pracy za pośrednictwem platform „może być najpełniej zrozumiany z egzotycznej, i początkowo kontrintuicyjnej, perspektywy, gdzie problemem jest nie binarny charakter roli pracownika, ale unitarny charakter roli pracodawcy" (Davies \& Freedland, 2006, s. 273-274). Innymi słowy - do pomyślenia jest model, gdzie pracodawcą nie jest jeden z góry określony podmiot; to, kto odgrywa rolę pracodawcy, zależeć będzie od funkcji, jakie poszczególne podmioty będą pełnić we wzajemnych relacjach. Gospodarek (2019a, s. 12-15) taki konglomerat wzajemnych powiązań nazywa „Zwielokrotnianiem centrów zainteresowań". Tego rodzaju podejście możemy określić jako funkcjonalne, a tak zdefiniowanego pracodawcę - jako pracodawcę funkcjonalnego (Prassl, 2016, s. 69-73).

Taki zabieg skutkować będzie rekonceptualizacją pojęcia „pracodawca”. Przyjdzie nam to łatwiej, gdy zdamy sobie sprawę, że tradycyjne unitarne pojmowanie podmiotu odgrywającego rolę pracodawcy i tak brało pod uwagę różne liczne funkcje wykonywane przez mocniejszą stronę stosunku pracy, takie jak: dostarczanie pracy, zapłata wynagrodzenia, ryzyko gospodarcze czy rozwiązywanie stosunku pracy (Prassl \& Risak, 2015; Salwa, 1986, s. 115). Zorientowanie się na poszczególne funkcje pracodawcy pozwoli pokonać problematykę wielostronnych relacji kontraktowych w ramach platform. Rezultatem będzie uznanie, że wszystkie funkcje pracodawcy pełni jedna platforma albo że funkcje te są rozproszone pomiędzy klientem platformy, samą platformą a usługodawcą (czyli że pracodawca ma charakter wielopodmiotowy).

Poprzez funkcje pracodawcy rozumiem działania, do których jest on zobligowany lub upoważniony na podstawie przepisów. Regulacje prawa pracy nie operują pojęciem funkcji pracodawcy i jako takie nie są one wprost nazwane w przepisach. Analiza relacji pracownik - pracodawca na gruncie Kodeksu pracy pozwala jednak wyodrębnić co najmniej takie funkcje, jak: kształtowanie treści stosunku pracy (od nawiązania, poprzez zmianę po rozwiązanie), pobieranie pracy i efektów pracy wykonywanej na rzecz pracodawcy, zarządzanie sposobem wykonywania pracy, zapłata wynagrodzenia i zarządzanie ryzykiem gospodarczym (Bigaj, 2016; Duraj, 2013; Goździewicz, 2017). Żadna ze wskazanych funkcji nie może samodzielnie stanowić o powstaniu stosunku 
pracy. Dopiero ich połączenie tworzy sytuację, w której jedna ze stron może być określona jako pracownik, a druga jako pracodawca. Takie funkcjonalne podejście do rozumienia pracodawcy powoduje, że analizując sytuację usługodawców świadczących pracę za pośrednictwem platform, mniejszego znaczenia nabierać będzie umowne wskazanie, kto jest pracodawcą, a większego - jaki podmiot lub jakie podmioty, pełnią poszczególne funkcje pracodawcze. Funkcje te mogą być bowiem pełnione wszystkie łącznie zarówno przez jedną platformę, jak i przez różne podmioty.

Uber stanowi przykład modelu, w którym wszystkie funkcje pracodawcy pełnione są przez jedną platformę $e^{2}$.

Po pierwsze, platforma ma pełną kontrolę nad nawiązaniem relacji z kierowcą i nad jej zakończeniem. Kierowca musi się zarejestrować, używając jej systemu i narzędzi. Uber weryfikuje uprawnienia kierowców, stan pojazdów i ubezpieczenie oraz w każdej chwili może jednostronnie zakończyć dostęp kierowcy do platformy. Jak stwierdził jeden z kierowców „Koszmarem każdego z nas jest e-mail o dezaktywacji konta. Jesteś zwolniony bez ostrzeżenia i wyjaśnienia" (Smith, 2015). Powrót do świadczenia usługi jest zwykle możliwy po odbyciu szkolenia. Co więcej, klient platformy także nie pełni jakiejkolwiek funkcji w tym zakresie - nawet nie wie, kim jest kierowca, ani który z dostępnych kierowców w ogóle zareaguje na jego zlecenie. Także wpływ kierowców na wybór klienta jest ograniczony, gdyż muszą oni zaakceptować $80 \%$ zleceń nadchodzących w czasie ich dostępności, a po przyjęciu zlecenia nie mogą go odrzucić.

Po drugie, Uber jest beneficjentem pracy świadczonej przez kierowców. To platforma automatycznie pobiera wynagrodzenie od klienta, wystawia faktury i zajmuje się reklamacjami. Cały jej system skonstruowany jest w ten sposób, aby wyeliminować jakikolwiek finansowy element między kierowcą a klientem (łącznie ze wspomnianym zakazem pobierania napiwków).

Po trzecie, Uber w pełni koordynuje sposób wykonywania pracy dzięki wydawanym przez siebie instrukcjom i regulaminom, a dzięki zastosowaniu nowoczesnych narzędzi informatycznych i geolokalizacyjnych ma pełną wiedzę co do sposobu wykonywania usługi. Co więcej, platforma określa też rodzaj pojazdów, jakie powinny być stosowane przez kierowców, w określonych sytuacjach weryfikuje ich stan techniczny, uszkodzenia lakieru oraz czystość wewnątrz auta, a nawet wydaje rekomendacje co do tego, w jakich sytuacjach i pod jakimi warunkami można włączać muzykę. Jak powiedział Ben Sachs: „Platforma oczekuje od klientów oceny wykonania usługi, określa sposób wykonywania usługi i na

\footnotetext{
2 https://www.uber.com/legal/terms/us/ (dostęp: 19.04.2019).
} 
podstawie tych dwóch czynników podejmuje decyzje o dalszym zatrudnieniu. Tak robią pracodawcy" (Sachs, 2015).

Po czwarte, kierowcy Uber nie mają żadnego wpływu na poziom cen stosowanych przez Uber i otrzymują wynagrodzenie bezpośrednio od platformy, nigdy od jej klientów.

Po piąte wreszcie, to Uber ponosi ryzyko gospodarcze prowadzonego przez siebie przedsiębiorstwa. To platforma pobiera zyski, jest wyeksponowana na stratę, ustala ceny usług i zapewnia wizualizację korporacyjną oraz reklamę.

Powyższe wskazuje, że platforma taka jak Uber, pomimo prowadzenia swojego modelu biznesowego opartego na nowoczesnych narzędziach cyfrowych, spełnia wszystkie funkcje pracodawcy dla zatrudnionych za jej pośrednictwem usługodawców. Mamy tu więc do czynienia z unitarnym charakterem pracodawcy.

Możliwe są jednak sytuacje, w których poszczególne funkcje pracodawcze wykonywane będą przez różne podmioty. Konkretne funkcje mogą być wprawdzie przypisane różnym podmiotom, ale możliwe jest również, że jedna funkcja będzie należeć do kilku podmiotów. To w takim środowisku klasyczne rozumienie pracodawcy napotyka największy intuicyjny opór. Może się bowiem nawet okazać, że skoro to klient platformy pełni funkcje pracodawcze, podlega on określonym obowiązkom regulacyjnym.

Taki wielostronny model można zaobserwować na przykładzie platformy TaskRabbit, służącej do zlecania usług drobnych prac naprawczych ${ }^{3}$.

Funkcja nawiązywania, kształtowania i rozwiązywania zatrudnienia należy tu do samej platformy. TaskRabbit sprawdza historię i reputację usługodawców przed dopuszczeniem ich do świadczenia usług oraz deaktywuje konta w razie naruszenia regulaminu i skarg od klientów. W odróżnieniu jednak od innych platform TaskRabbit nie usuwa konta usługodawcy, gdy jego rating spadnie poniżej z góry określonego poziomu (choć konsekwencją może być przyjmowanie jedynie słabo płatnych zleceń).

Funkcja pobierania efektów pracy również należy do TaskRabbit. To platforma wystawia faktury i otrzymuje wynagrodzenie od klientów. Między usługodawcą a klientem nie ma żadnych przepływów finansowych.

Funkcja zarządzania sposobem pracy jest podzielona między platformę, jej klienta i usługodawcę. Sposób wykonywania poszczególnych prac jest tu określany przede wszystkim przez klientów zamawiających konkretną usługę. TaskRabbit ogranicza się do usuwania zleceń obejmujących prace niebezpieczne

\footnotetext{
https://www.taskrabbit.com/terms (dostęp: 11.05.2019).
} 
lub nielegalne i mocno podkreśla konieczność osobistego świadczenia usług przez usługodawców.

Funkcje związane $\mathrm{z}$ wynagrodzeniem usługodawcy również są tu podzielone: TaskRabbit nie ustala wysokości wynagrodzenia; to zadanie należy do samych klientów lub do usługodawców. Platforma wypłaca natomiast wynagrodzenie usługodawcom.

Wreszcie funkcja ryzyka gospodarczego także jest rozparcelowana pomiędzy klienta, platformę i usługodawcę. Niektórzy klienci sami dostarczają narzędzia do wykonania pracy, platforma promuje i reklamuje swoją markę, a usługodawcy ustalają poziom cen.

Powyższy przykład obrazuje sytuację, gdzie różne funkcje pracodawcze pełnione są przez różne podmioty. Prawo pracy powinno zatem uznać i chronić taki funkcjonalny model pracodawcy, gdzie wykonywanie określonych zadań i uprawnień pracodawczych tworzy określone obowiązki bez względu na to, jakie relacje umowne leżą u ich podstaw (Deakin, 2001, s. 75-80). Dla analizy określonego kontekstu związanego ze świadczeniem usług poprzez platformę konieczne powinno być więc każdorazowo określanie, kto wykonuje daną funkcję. Pracodawcą funkcjonalnym może być zatem jeden podmiot albo kilka podmiotów odgrywających decyzyjną rolę w wykonywaniu określonych funkcji (Fudge, 2006). Oznacza to, że dla danego pracownika w danej sytuacji faktycznej może pojawić się kilka podmiotów, z których każdy może być potencjalnie pracodawcą. Dopiero wykonywanie w takiej sytuacji poszczególnych funkcji będzie skutkować przypisaniem statutu pracodawcy i odpowiedzialności w zakresie danej funkcji. Funkcja pracodawcza skutkowałaby zatem odpowiedzialnością pracodawczą w tym zakresie. W zależności od wagi różnych funkcji pracodawcy przepisy mogą przypisać mu różną odpowiedzialność.

Dla przykładu - zupełne inaczej powinna wyglądać sytuacja młodego pracownika, który debiutuje na platformie, oferując sprzątanie domów wedle stawek sugerowanych przez platformę, a inaczej sytuacja doświadczonego informatyka, który poprzez platformę tworzy aplikacje sprzedażowe. W pierwszym przykładzie mamy kogoś, kto przyjmuje stawki narzucone przez platformę, otrzymuje wynagrodzenie za pośrednictwem platformy i ma słabą wobec niej pozycję negocjacyjną. W drugim - usługodawca może wybierać klientów, negocjować stawki, promować swoją reputację i w każdej chwili może platformę swobodnie opuścić. W pierwszej sytuacji wszystkie funkcje pracodawcy pełnić będzie platforma; choć dopuszczalny jest przypadek, w którym dany klient zleci zadanie w specyficznych warunkach i wówczas to klient pełnić będzie jedną z funkcji pracodawczych (zarządzenie pracą). W drugiej sytuacji mamy osobę samoza- 
trudnioną, ale może się okazać, że stosowany przez platformę algorytm łączenia klientów i usługodawców dyskryminuje danego wykonawcę z określonych przyczyn - wówczas to platforma ponosić będzie odpowiedzialność za naruszenie zasady równego traktowania w zatrudnieniu (Johnson, 2013).

\section{Praca nakładcza?}

Kolejną możliwością legalnego ujęcia sytuacji pracy świadczonej za pośrednictwem platform może być zrewidowany i zmodernizowany model pracy nakładczej. Korzystanie bowiem z pracy osób samozatrudnionych, będących w słabej pozycji ekonomicznej i wykonujących obowiązki w swoim domu, ma długą tradycję (Boris \& Daniels, 1989). Taki model był popularny w Europie we wczesnej fazie industrializacji w XIX wieku, ale także w pierwszej połowie wieku XX w obliczu perturbacji wojennych i globalnej recesji lat 30. (Finkin, 2016, s. 609-614). Zleceniodawca rozdysponowywał pracę bezpośrednio albo za pośrednictwem agentów wykonawcom, którzy wykonywali zadania albo $\mathrm{w}$ domu, albo w miejscach wskazanych przez zleceniodawcę. Z czasem w wielu krajach regulowano tę formę pracy, wyposażając ją m.in. w płacę minimalną dla zapobieżenia negatywnym skutkom wykorzystania taniej siły roboczej. Zresztą przez większą część nowożytnych dziejów praca wytwórcza była wykonywana w domach (Braudel, 1992, s. 151-161). Dopiero z czasem potrzeby m.in. większego nadzoru nad pracą oraz ukrócenia kradzieży materiału powierzanego wytwórcom spowodowały centralizowanie pracy w fabrykach (Marglin, 1974).

W Polsce ta forma zatrudnienia cieszyła się popularnością jeszcze w latach 70. ubiegłego wieku. Zwykle obejmowała ona wykonywanie w domu (stąd też nazwa - praca chałupnicza) prostych prac na rzecz nakładcy z powierzonych przez niego materiałów. Występowanie tego modelu pracy sukcesywnie malało wobec mechanizacji i automatyzacji zadań wykonywanych zwykle przez wykonawców (skręcanie długopisów, wytwarzanie guzików, produkcja taniej biżuterii, produkcja sztucznych kwiatów czy zabawek, montowanie pędzli). Powrót zainteresowania pracą nakładczą pojawił się wraz ze zwiększoną popularnością telepracy.

Obecnie praca nakładcza uregulowana jest w Rozporządzeniu Rady Ministrów Z 31 grudnia 1975 r. w sprawie uprawnień pracowniczych osób wykonujących pracę nakładczą (Dz.U. z 1976 r. poz. 19 ze zm.). Umowa o pracę nakładczą polega na wytwarzaniu przez wykonawcę przedmiotów lub ich części z powierzonego materiału lub na świadczeniu usług na polecenie i rachunek zlecającego, czyli 
nakładcy. Od umowy o pracę odróżnia ją to, że praca nie jest tu wykonywana pod nadzorem zlecającego, nadzorca nie ma wpływu na wybór czasu i miejsca świadczenia pracy, a wykonawca może powierzyć wykonanie zadań osobie trzeciej. Dodatkowo nakładca nie musi utrzymywać stanowiska pracy i zmniejsza swoje ryzyko gospodarcze, gdyż rozlicza się z wykonawcą wyłącznie za zlecone i wykonane zadania.

Wydaje się, że taki rodzaj stosunku zatrudnienia odpowiada cechom pracy za pośrednictwem platform. Nakładca (tak jak platforma) nie wydaje poleceń co do sposobu wykonywania pracy i nie sprawuje kierownictwa nad wykonawcą. W obu systemach praca wykonawców ma charakter zdecentralizowany: fizycznie są oni odizolowani od siebie i od nakładcy. Nakładca (tak jak platforma) nie ponosi kosztów nadzoru i zarządzania pracą. Wykonawcy są rozliczani i wynagradzani za wykonane zadanie, a tym samym ich tempo i sposób pracy nie muszą być weryfikowane. Nakładca nie ponosi ryzyka gospodarczego - rozlicza się z wykonawcą za zleconą i wykonaną pracę i nie płaci miesięcznego wynagrodzenia, którego wartość jest oderwana od zysku nakładcy. Pozostawia to nakładcy dużą swobodę i elastyczność w reagowaniu na popyt na swoje usługi lub produkty. Nakładca nie ponosi tym samym kosztów stałych związanych z zatrudnieniem. W obu systemach mamy do czynienia z niskimi na ogół zarobkami (dodatkowo zwraca się uwagę, że zarówno w przypadku pracy nakładczej, jak i platform dominuje praca wykonywana przez kobiety - Difallah, Filatova \& Ipeirotis, 2018), które zwykle stanowią zarobek dodatkowy obok głównego źródła utrzymania (Difallah, Filatova \& Ipeirotis, 2018). Nakładca nie ponosi tu kosztu inwestycyjnego w postaci nieruchomości czy sprzętu. Każdy wykonawca pracuje niezależnie ze swojego domu lub poza domem przy wykorzystaniu swoich narzędzi. W obu systemach wykonywane są w większości proste zadania4 ${ }^{4}$. Wreszcie brak kontaktu między wykonawcami skutkuje brakiem więzi między nimi i brakiem realnej możliwości artykułowania zbiorowych interesów wykonawców (de Stefano, 2017).

Przewidziane we wskazanym rozporządzeniu warunki pracy nakładczej wydają się oddawać charakter rozkładu ryzyk platformy i osoby świadczącej pracę za jej pośrednictwem. $Z$ jednej bowiem strony wykonawca musi mieć zapewnioną taką ilość pracy, by uzyskać gwarancję określonego dolnego poziomu wynagrodzenia (odpowiadającego 50\% wartości płacy minimalnej lub $100 \%$ wartości płacy minimalnej w zależności od tego, czy praca nakładcza stanowi dla niego główne źródło utrzymania), z drugiej zaś strony nakładca płaci

4 Za ponad 90\% prac wykonywanych na platformie Amazon Mechanical Turk wynagrodzenie wynosi mniej niż 10 centów amerykańskich. Zob. Mandl, Curtarelli, Riso, Vargas Llave \& Georgiannis, 2015, 
wyłącznie za wykonaną pracę. Przepisy zapewniają także wykonawcy ochronę przed nieuzasadnionym wypowiedzeniem, przewidują tradycyjne pracownicze korzyści, takie jak urlopy, obowiązek nakładcy zwrotu kosztów poniesionych przez wykonawcę na wykonanie pracy czy wreszcie ograniczenie odpowiedzialności wykonawcy za szkodę wyrządzoną nakładcy wskutek nienależytego wykonania obowiązków wynikających z umowy.

Zorganizowanie pracy crowdworkingowej na bazie modelu pracy nakładczej korzysta z jego zalet, pozwalając równocześnie wyeliminować jego historyczne słabości. Tradycyjnie bowiem brak kontaktu między wykonawcami nie pozwalał na generowanie nowych pomysłów, z których nakładca mógł korzystać. Dziś, biorąc pod uwagę współczesne narzędzia technologiczne, zarówno wykonawcy, jak i nakładca mogą być w ciągłym kontakcie, by wymieniać doświadczenia i pomysły. Praca nakładcza w perspektywie historycznej stawała się coraz mniej popularna, gdyż była zastępowana maszynami i automatami. Teraz z kolei może nastać jej renesans, gdyż platformy i nowe narzędzia komputerowe stwarzają szanse na zarządzanie taką pracą od prostych czynności, jak sprzątanie i prowadzenie pojazdów, po skomplikowane zadania informatyczne.

Obecne rozporządzenie regulujące pracę nakładczą ma ponad 40 lat. Bez wątpienia wymaga ono dostosowania do współczesnych trendów w zatrudnieniu, nowoczesnych narzędzi technologicznych oraz do oczekiwań nowych generacji pracodawców i pracowników. Okazją do zrewidowania tego dokumentu i uregulowania pracy nakładczej na nowo, tak by odpowiadała ona warunkom zatrudnienia opartego o platformy, może być Konwencja nr 177 z 20 czerwca 1996 r. Międzynarodowej Organizacji Pracy dotycząca pracy nakładczej5.

\section{Zakończenie}

Świadczenie pracy i usług za pośrednictwem platform w ramach nowego modelu biznesowego gig-economy odbywa się w warunkach zupełnie innych niż tradycyjne. Nie przeprowadza się szkoleń. Dominują mikro-zadania. Pracuje się $\mathrm{w}$ swoim domu, zdalnie, $\mathrm{w}$ domu klienta lub innym miejscu wskazanym przez platformę i przy wykorzystaniu własnych narzędzi. Angażuje się pracownika na godziny, czasami na minuty czy nawet sekundy. Proces decyzyjny i zarządzanie pracą po stronie platformy są zautomatyzowane i zalgorytmizowane. Wykonawca usługi nie ma żadnej ochrony socjalnej ani zabezpieczeń przewidzianych prawem

\footnotetext{
5 Międzynarodowa Organizacja Pracy w Genewie, 2000.
} 
pracy. Wynagrodzenie płatne jest za wykonaną usługę i uzależnione od aprobaty klienta. Wykonawca musi cały czas pozostawać w gotowości do przyjęcia zadania i nie ma możliwości podjęcia działań zbiorowych.

Zatrudnienie w ramach platform to nowa faza cyfrowej transformacji pracy. W literaturze przedmiotu jest ono ujmowane jako istotny element zmian w ramach tzw. Przemysłu 4.0 (Rojszczak, 2019, s. 9 ). Skupia ono w sobie takie zjawiska, jak: niestabilność zatrudnienia, automatyzację i algorytmizację zarządzania oraz coraz bardziej obniżające się wymogi względem kwalifikacji osób potrzebnych do wykonywania usługi. W rezultacie przedstawia ono raczej ponury i niepokojący obraz.

Tym większego znaczenia nabiera odpowiedni dobór regulacji prawnej, w której taka praca powinna się odbywać. Obowiązujący do tej pory paradygmat indywidualnego stosunku pracy, w przypadku osób świadczących usługi za pośrednictwem platform, winien ulec dogłębnej rekonceptualizacji.

\section{Bibliografia}

Aloisi, A. (2016). Commoditized workers: Case study research on labor law issues arising from a set of "on-demand/gig economy" platforms. Comparative Labor Law \& Policy Journal, $37(3)$.

Baylos Brau, A. P. (2000). La 'huida' del derecho del trabajo. W: M. A. Caracuel, M. M. Hernandez (red.), El trabajo ante el cambio de siglo: un tratamiento multidisciplinar: aspectos laborales, fiscales, penales y procesales (ss. 35-36). Madryt, Hiszpania: Marcial Pons.

Bigaj, A. (2016). Z problematyki zatrudnienia cywilnoprawnego w polskim porządku prawnym. Palestra, 12.

Boris, E., \& Daniels, C. R. (1989). Homework: historical and contemporary perspectives on paid labor at home. Champaign. Stany Zjednoczone: University of Illinois Press.

Braudel, F. (1992). Civilization and Capitalism, 15th-18th Century. Vol. I: The structure of everyday life. Berkeley, CA:University of California Press.

Cherry, M. A. (2016). Beyond misclassification: the digital transformation of work. Comparative Labor Law \& Policy Journal, 37 (3).

Cherry, M. A. (2009). Working for (virtually) minimum wage: applying the fair labors standards act in cyberspace. Alabama Law Review, 6o(5).

Davidov, G. (2016). A purposive approach to labor law. Oxford, Anglia: Oxford University Press.

Davies, P., \& Freedland, M. (2006). The complexities of the employing enterprise. W: G. Davidov \& B. Langile (red.), Boundaries and Frontiers of Labor Law (ss. 273-274). Oxford, Wielka Brytania: Hart Publishing. 
Deakin, S. (2001). The changing concept of the 'employer' in labor law. Industrial Law Journal, 30(1), 75-80.

Difallah, D., Filatova, E., \& Ipeirotis, P. (2018, luty). Demographics and dynamics of mechanical turk workers. Wygłoszone na Eleventh ACM International Conference on Web Search and Data Mining w Marina del Rey, CA. Pozyskano z http://www. ipeirotis.com/wp-content/uploads/2017/12/wsdmfo74-difallahA.pdf (dostęp: 11.05.2019).

De Pillis, L. (2015). New tech companies say freelancing is the future of work - but there's a downside for workers. Washington Post. Pozyskano z https://www. washingtonpost.com/news/storyline/wp/2015/02/03/new-tech-companies-say-freelancing-is-the-future-of-work-policy-needs-to-catch-up/ (dostęp: 2.05.2019).

De Stefano, V. (2017). Non-standard work and limits on freedom of association: a human-rights based approach. Industrial Law Journal, 46(2).

De Stefano, V. (2016). The rise of the "Just-in-time" workforce: On-demand work, crowd work and labor protection in the gig-economy. Genewa, Szwajcaria: Międzynarodowa Organizacja Pracy.

Duraj, T. (2013). Zależność ekonomiczna jako kryterium identyfikacji stosunku pracy analiza krytyczna. Praca i Zabezpieczenie Społeczne, 6.

Felstiner, L. (2011). Working the crowd: employment and labor law in the crowdsourcing industry. Berkeley Journal of Employment and Labor Law, 32(1).

Finkin, M. (2016). Beclouded work in historical perspective. Comparative Labor Law \& Policy Journal, 37(3), 609-614.

Florek, L. (1990). Ochrona praw i interesów pracownika. Warszawa, Polska: Państwowe Wydawnictwo Naukowe.

Fudge, J. (2006). Fragmenting work and fragmenting organizations: the contract of employment and the scope of labor regulation. Osgoode Hall Law Journal, 44(6).

Gaweł, A. (2019). Pracownik czy przedsiębiorca? Teoria wyboru zajęcia zawodowego w wyjaśnianiu decyzji o formie aktywności zawodowej. Praca i Zabezpieczenie Społeczne, 6, s. 6.

Gospodarek, G. (2019a). Status „niezależnego” usługodawcy a trójpodmiotowy model świadczenia usług w gig economy - cz. 1. Praca i Zabezpieczenie Społeczne, 2, 12.

Gospodarek, G. (2019b). Status „niezależnego” usługodawcy a trójpodmiotowy model świadczenia usług w gig economy - cz. 2. Praca i Zabezpieczenie Społeczne, 4.

Goździewicz, G. (2017). Komentarz do art. 22 Kodeksu Pracy. W: L. Florek (red.), Kodeks pracy. Warszawa, Polska: Wolters Kluwer Polska.

Hong, E. (2015, październik). Making it work: a closer look at the gig-economy. New America. Pozyskano z https://www.newamerica.org/weekly/94/making-it-work-a-closer-look-at-the-gig-economy/ (dostęp: 3.05.2019). 
Howe, J. (2006, czerwiec). The rise of crowdsourcing. Wired. Pozyskano z https://www. wired.com/2006/o6/crowds/ (dostęp: 5.05.2019).

Huet, E. (2014, październik). Uber deactivated a driver for tweeting a negative story about Uber. Forbes. Pozyskano z https://www.forbes.com/sites/ellenhuet/2014/10/16/ uber-driver-deactivated-over-tweet/\#324114836a4c (dostęp: 13.05.2019).

Huws, U. (2003). The making of a cybertariat: Virtual work in a real world. Nowy Jork, NY: Monthly Review Press.

Jankowiak, J. (2001). Pracodawcze prawo do wydania polecenia (wydawania poleceń) na tle koncepcji prywatnoprawnej czynności trwałej. Państwo i Prawo, 4.

Johnson, C. (2013, sierpień). The pitfalls of crowdsourcing: online ratings vulnerable to bias. Boston Globe. Pozyskano z https://www.boston.com/news/science/2013/o8/o8/the-pitfalls-of-crowdsourcing-online-ratings-vulnerable-to-bias (dostęp: 10.05.2019).

Mandl, I., Curtarelli, M., Riso, S., Vargas Llave, O., \& Georgiannis, E. (2015). New forms of employment. Eurofound, 1 .

Manjoo, F. (2015, styczeń). Uber's business model could change your work. New York Times. Pozyskano z https://www.nytimes.com/2015/01/29/technology/personaltech/uber-a-rising-business-model.html (dostęp: 2.05.2019).

Marglin, S. (1974). What do bosses do? The origins and functions of hierarchy in capitalist production. Part I. The Review of Radical Political Economics, 6(2).

Marvit, M. (2014, luty). How crowdworkers became the ghosts in the digital machine. The Nation. Pozyskano z https://www.thenation.com/article/how-crowdworkers-became-ghosts-digital-machine/ (dostęp: 3.05.2019).

Mian, E. (2016, styczeń). In praise of the gig economy. The Telegraph. Pozyskano z https:// www.telegraph.co.uk/technology/uber/12086500/In-praise-of-the-gig-economy. html (dostęp: 7.05.2019).

Pisarczyk, Ł. (2012). Cele prawa pracy a jego funkcje ochronna i organizacyjna. Praca i Zabezpieczenie Społeczne, 12, 3-7.

Prassl, J. (2016). The concept of the employer. Oxford, Wielka Brytania: Oxford University Press.

Prassl, J., \& Risak, M. (2015). Uber, Task Rabbit \& Co: platforms as employers? Rethinking the legal analysis of crowdwork. Comparative Labor Law \& Policy Journal, 37(3).

Rogers, B. (2016). Employment rights in the platform economy: getting back to basics. Harvard Law \& Policy Review, 10(1).

Rojszczak, M. (2019). Wpływ robotyzacji na rynek pracy i sektor ubezpieczeń społecznych. Praca i Zabezpieczenie Społeczne, 7, 9 
Sachs, B. (2015, maj). Uber and Lyft: customer reviews and the right to control. On Labor. Pozyskano z https://onlabor.org/uber-and-lyft-customer-reviews-and-the-right-to-control/ (dostęp: 10.05.2019).

Salwa, Z. (1986). Organizacyjna funkcja prawa pracy. Studia Prawnicze, 3-4, 115.

Semuels, A. (2018, styczeń). The internet is enabling a new kind of poorly paid hell. The Atlantic. Pozyskano z https://www.theatlantic.com/business/archive/2018/o1/ amazon-mechanical-turk/551192/ (dostęp: 8.05.2019).

Skąpski, M. (2006). Ochronna funkcja prawa pracy w gospodarce rynkowej. Warszawa, Polska: Wolters Kluwer Polska.

Smith, J. (2015, luty). Uber drivers: the punishment for bad rating is costly training courses. The Observer. Pozyskano z https://observer.com/2015/02/uber-drivers-the-punishment-for-bad-ratings-is-costly-training-courses/ (dostęp: 10.05.2019).

Sprague, R. (2015). Worker (mis)classification in the sharing economy: Square pegs trying to fit in round holes, A.B.A. Journal of Labour \& Employment Law, 31(1), 59-70.

Świątkowski, A. M. (2019). Digitalizacja prawa pracy. Praca i Zabezpieczenie Społeczne, 3, 15-16.

Świątkowski, A. M. (2019). Nowe, nietypowe formy zatrudnienia w epoce postindustrialnej. Polityka Społeczna, 46(1).

Todoli-Signes, A. (2017). The end of the subordinate workers? Collaborative economy, on-demand economy, gig-economy and the crowdworkers' need for protection. International Journal of Comparative Labor Law and Industrial Relations, 33(2).

Weber, P. M., \& Turcios, E. N. (2015, czerwiec). Uber hits a speedbump in California: labor commissioner rules driver is an employee. Pillsbury Client Alert. Pozyskano $\mathrm{z}$ https://www.pillsburylaw.com/images/content/1/1/v2/1141/AlertJune2015LitigationUberHitsaSpeedBumpinCalifornia.pdf (dostęp: 5.05.2019).

Weil, D. (2014). The fissured workplace: why work became so bad for so many and what can be done to improve it. Cambridge, Wielka Brytania: Harvard University Press.

Zatz, N. D. (2011). Beyond misclassification: tackling the independent contractor problem without redefining employment, A.B.A. Journal of Labour \& Employment Law, 26(2).

\section{Orzecznictwo}

Wyrok Europejskiego Trybunału Sprawiedliwości z 20.12.2017 r., C-434/15, Asociacion Profesional Elite Taxi v. Uber Systems Spain, ECLI:EU:C:2017:981.

Wyrok England and Wales Court of Appeal (Civil Division) z 19.12.2018 r., EWCA Civ 2748, Y. Aslam vs. Uber London Limited.

Wyrok United States Court of Appeal for the Ninth District, Cotter vs. Lyft, 6o F. Supp. 3d 1067 (N. D. Cal 2015). 


\section{Akty prawne}

Ustawa z 26.01.1982 r. - Karta Nauczyciela (tj. Dz.U. z 2018 r. poz. 967 ze zm.).

Ustawa z 27.07.2001 r. o diagnostyce laboratoryjnej (tj. Dz.U. z 2019 r. poz. 849).

Ustawa z 16.04.2004 r. o czasie pracy kierowców (tj. Dz.U. z 2012 r. poz. 1155 ze zm.).

Ustawa z 15.07.2011 r. o zawodach pielęgniarki i położnej (tj. Dz.U. z 2019 r. poz. 576 ze zm.).

Międzynarodowa Organizacja Pracy w Genewie (2000). Konwencja dotyczaca pracy nakładczej nr 177 z 20 czerwca 1996 r. Pozyskano z https://www.ilo.org/dyn/ normlex/en/f?p=NORMLEXPUB:12100:0::NO::P12100_INSTRUMENT_ID:312322 (dostęp: 14.05.2019).

\section{Streszczenie}

Przedmiotem artykułu jest analiza zatrudnienia za pośrednictwem platform działających w ramach nowego modelu biznesowego, określanego jako platform economy, gig economy, on-demand economy czy sharing economy, oraz wskazanie, że nigdy dotąd prawo pracy nie musiało zmierzyć się z zatrudnieniem w takich niepokojących warunkach. Autor opisuje cechy pracy w systemie crowdsourcing, jej zalety i wady, oraz wskazuje, dlaczego osoby świadczące usługi za pośrednictwem platform nie są chronione prawem pracy. Artykuł rekomenduje dostosowanie środowiska prawnego do takich nowych, cyfrowych form zatrudnienia poprzez wybrane formy: specustawę dla cybertariatu, pojęcie pracodawcy funkcjonalnego oraz renesans umowy o pracę nakładczą.

SŁoWA KLUCzOWE: cybertariat, samozatrudnienie, nietypowe zatrudnienie, pracodawca funkcjonalny, praca nakładcza

\section{Summary}

The article delves into disturbing questions that arise in attempting to apply traditional employment and labour law to crowdsourcing, an emerging online labour model unlike any other so far. The author describes how crowdsourcing works, its advantages as well as perils, and indicates why workers of such industry are denied the safeguards of employment laws without proper recourse to vindicate their rights. The article explores the nature of this new and atypical employment relationship in order to determine the legal status of the digital workers and then claims that new legal tools, namely the special law for crowd workers, the notion of functional employer and the revival of putting-out system, may be applied to such employment.

KEYwORDs: cybertariat, crowdsourcing, self-employment, functional employment, putting-out system

\section{Nota o autorze}

Mgr Radosław T. Skowron - adwokat, LEGAL SKILLS POLAND Basiński, Morawski, Kuca, Skowron Adwokacka Spółka Partnerska, Kraków, e-mail: rs@legalskills.eu, r.skowron@bmk-adwokaci.pl. 